INTERNATIONAL JOURNAL OF MULTidisciplinARY RESEARCH AND ANALYSis

ISSN(print): 2643-9840, ISSN(online): 2643-9875

Volume 05 Issue 02 February 2022

DOI: 10.47191/ijmra/v5-i2-12, Impact Factor: 6.072

Page No.- 319-327

\title{
Effect of Corporate Governance on Financial Distress: Evidence from Listed Firms at Ghana Stock Exchange
}

\author{
Alex Abugri
}

ABSTRACT: This study was conducted to determine the effect of corporate governance on financial distress of listed firms at Ghana Stock Exchange (GSE) using panel data from 2015 to 2019. Specifically, the study focusses on: The effect of board size on financial distress of listed firms at GSE, the effect of board gender diversity on financial distress of listed firms at GSE, the effect of ownership concentration on financial distress of listed firms at GSE and the effect of number of non-executives on financial distress of listed firms at GSE. OLS Regression Model has been conducted using EVIEWS 11. The data has been validated using normality, multicollinearity and Heteroscedascity test as recommended by previous research due to their robustness. The study found that $15.5 \%$ variability in financial distress of listed companies is explained by corporate governance practices of the listed companies. This result suggests that a unit change in corporate governance practices will bring about $12.5 \%$ changes in financial distress management. The study found that board size was significant determinant of financial distress. Again, the study further found that board diversity was significant determinant of financial distress. Moreover, the study found that managerial experience of the board was significant determinant of financial distress. However, non-executive and capital structure was not determinants of financial distress. The study concludes that corporate governance exerted significant influence on financial distress of listed firms at Ghana Stock Exchange. The study recommends that selected firms at GSE must develop and formulate good policies to help regulate and manage board members so that the decision-making process of the firm can be facilitated to achieve firm goals and objectives while maintaining financial stability.

KEYWORDS: Corporate Governance, Financial Distress, OLS Model, Ghana Stock Exchange

\section{INTRODUCTION}

Corporate governance denotes maximum honesty and intensity in production of an organization. Different contributors in the organizations such as; managers, stakeholders, board as well as directors are assigned with privileges and duties by corporate governance and give clarification on governance that runs affairs of businesses. Management decisions automatically affect the firms' direction (Datta, 2018; Kamau, 2018). Decisions are therefore established on shareholding composition, financial prospects due to firms capabilities, corporate governance and arising economic factors on the market (Lamichhane, 2018).

Financial distress is widely considered as various instances where firms encounter financial challenges. Bankruptcy, insolvency and failure are some basic factors that are used to describe financial distress (Maina and Sakwa, 2012). In unexpected cases, situations that strongly hit an organization is referred to as financial distress. Senbet and Wang (2012) also interpreted financial distress as occasion where contracts and creditors extremely go bankrupt. Managers' decisions have significant relationship with finances in the firm therefore inappropriate financial decisions strongly affects firms' operations (Sanda et al. 2005). Financial distress worsens when firm fails to gather enough resources to cater for dues on time. Firms' finances may face total bankruptcy or liquidation with regards to less assistance in bit to settle their dues (Hu, 2011).

\section{Problem Statement}

The banking sectors take is the central focus of regional, local and worldwide banks. Several external and internal forces contribute to the establishment of the banks. Bank growth in Kenya's local banks is rapid. Rapid improvement in local banking sector serve as a major benefit to enhance the objectives of liberalization in finances, economy, competition among banks market, improve service to customers and enlarge credit asses in small-medium businesses in the locality. In real cases, Ghana as a nation does not have most of its firms on the stock list. Never-ending operation in firms' sometimes lead to failure and circumstances that were not predicted but this may not always be the reason for business failure (Senbet and Wang, 2012). Talian (2012) revealed that, foreseeing financial distress in Ghana was consistent with financial variables. Financial variables such as poor capital decisions, 


\section{Effect of Corporate Governance on Financial Distress: Evidence from Listed Firms at Ghana Stock Exchange}

poor internal management shortage of skilled labor and lack of access of credit attribute to distress in finances. Mandi (2014) concluded that, financial factors that lead to huge firms' future direction such as Ghanaian sovereign risk was detected by $Z$ score.

Wamugo, Makau and Kosimbei (2014) emphasized that, not all firms in Ghana are regarded as statutory management. Business after ensuring effective productivity by producing quality materials and unbeatable strategies still encounter financial distress, this is an indication that, success in businesses is achieved when there is efficient operation in the business by financial operators and managers in the firm. Globally, both developed and developing countries encounter financial distress. The research studied corporate governance, create awareness of financial distress in some firms in Ghana and recommend measures to get rid completely or reduce it and create policies to mitigate the challenges of moral hazard and therefore reduce the occurrences of financial distress. Moral hazard, lending large amount of money to customers without considering risk involved has led to financial distress in local banks hence local banks for the past years have been encountering financial difficulties, which has pose major threat on their effort to achieve higher benefits. The main objective of the study is to determine the effect of corporate governance on financial distress of listed firms at Ghana Stock Exchange (GSE). Specifically, the study will be guided by the following objectives: To determine the effect of board size on financial distress of listed firms at GSE; examine the effect of board gender diversity on financial distress of listed firms at GSE; determine the effect of number of non-executives on financial distress of listed firms at GSE, and assess the effect of ownership concentration on financial distress of listed firms at GSE.

\section{LITERATURE REVIEW}

\section{Corporate Governance}

Knell (2006) defined corporate governance as the process whereby corporate entities operate based on occupational laws and standards. Corporate governance as denote is the process whereby managers ensures that all occupational activities are regulated and governed by administrative measures and controlling mechanisms so that intended goals and objectives can be achieved. Ashbaugh et al (2004) revealed that, corporate governance is an instrument that can be used to avert business risks and irregularities in corporate entities.

Corporate governance was defined by the Cadbury Committee of U.K in 2002 as a system of operation whereby business activities are regulated and governed to ensure consistency and accountability. Corporate governance helps firms to achieve organizational goals and objectives especially in fulfilling the interest of shareholders. Corporate governance involves all activities that are in accordance with rules and regulations hence with managements' consent. Corporate governance ensures accountability, transparency and maintaining ethical standards. However, effective corporate governance must consist of shareholders, board of directors and management.

Corporate governance is the act of controlling, managing and regulating organizational activities to achieve desirable outcomes. According to Adams and Mehran (2008) corporate governance is the process of creating good atmosphere for good working conditions to improve performance and growth. Corporate governance is also the act of creating balance in the interest of shareholders, management, customers, supplier government and other stakeholders. Corporate governance reduces capital expenditure and helps organizations to achieve higher performance and growth.

To achieve successful corporate governance practices, firms need to deploy systems and measures that can help in the adoption of corporate governance practices, for instance examining the relevant structures that may identify the appropriate practices to sustain corporate governance practices (Aguilera \& Jackson, 2003; Dewji \& Miller, 2013; CMA, 2015).

Current study measured corporate governance using non-executive directors, board size, board gender diversity and ownership concentration.

\section{Financial Distress}

According to Emery, Finnerty and Stowe (2007), financial distress is a situation whereby financial goals and objectives are not met due to certain mismanagements or other related factors. Financial distress is firms' inability to engage into business competition as a result of financial drain, high deficits and other unfavourable conditions. Labie and Périlleux (2008) explained that financial distress is firms' inability to finance business activities and also unable to settle deficits. Financial distress is a stage in the business cycle whereby firms become financially incapable and unable to fulfill financial obligations. Outecheva (2007) indicated that financial distress may include decrease in profitability rate, poor cash flows, decrease in sales and other related indicators. Outecheva (2007) further showed that firms can become financially constrained even without a default portfolio, this maybe as a result of internal mismanagement and irregularities among top management. Aasen (2011) opined that there are two forms of financial distress cost and these include, direct insolvency cost and indirect insolvency cost. The direct cost deals with costs involving legal or lawful costs whereas the indirect insolvency cost deals with financial difficulties in business management. 


\section{Effect of Corporate Governance on Financial Distress: Evidence from Listed Firms at Ghana Stock Exchange}

Financial distress disrupts firms from growing especially when firm go bankruptcy. During this stage, cash flow is reduced, profit margin decreases as well as decrease in liquidity levels (Crutzen \& Van Caillie, 2007).

Financial distress is a situation in which a company's financial situation deteriorates to the point of bankruptcy. According to Altman and Hotchkiss (2006), corporate financial distress can be related to three common concepts used in business research: failure, bankruptcy, and insolvency. Failure occurs when the rate of return is not commensurate with the amount of capital invested, or when revenues are insufficient to cover costs because the average rate of return is systematically lower than the cost of capital. Financial distress occurs prior to a firm's bankruptcy proceedings.

\section{Theoretical Review}

The agency theory emphasis that, company owners delegates their responsibilities to management so that the management would take control and manage the affairs of the industry on behalf of the business owners (Jensen \& Meckling, 1976). In this appeal, conflict may arise between managers and business owners since there may be conflicting of interests between the management and shareholders. This however creates something called agency problems whereby initiative is taken by the business owner by establishing the board committee to act as the referee for both parties (Rodriguez-Fernandez et al., 2014).

Agency problem is created mainly as a result of separation of ownership and control. In that case, the agency theory had been developed with intent of helping resolve agency problems. The agency theory indicates that independent directors and credible external auditors is one of the essential mechanisms for monitoring the operations of management and also curbing agency conflicts. Monitoring systems put management on their toes to work as expected by business owners (Shin-Ping \& Tsung-Hsien, 2009). Management is always expected to ensure that all organizational activities are geared towards achievement of goals and objectives (Zouari \& Taktak, 2014). Nonetheless to maintain consistency and focus, there is the need for effective monitoring systems and practices so that management can be monitored to make sure that they stick with the intention of the organization.

\section{Empirical Review}

Bredart (2014) in the US context assessed the impact of board performance on financial distress. Bredart had already established that bankruptcy by firms had been increasing significantly ever since 2007. A study was therefore conducted to determine the cause of financial distress in most organizations. The study discovered that board size was a major factor affecting bankruptcy or financial distress in most organizations. This shows that, firms that have large board size are less likely to go bankruptcy than firms with small board size in the US.

Md-Rus, Mohd, Latif and Alassan (2013) study discovered that, ownership structure was a significant determinant on firm performance. However, study established that government ownership had no significant effect on financial performance of firms. Besides, government ownership was not a factor influencing the financial distress of organizations. In an attempt to determine the impact of ownership structure financial distress, logistic regression model was used. Result showed that, government ownership had no significant influence on firms' financial distress.

$\mathrm{Hu}$ and Zheng (2015) also deemed to explore whether ownership structure had any impact on financial distress of firms in China. The study found that, ownership structure was a factor that enables firms to reduce financial distress. Owners of organizations must therefore ensure that appropriate structures are developed to help maintain consistency and transparency in all organizational activities to enhance the financial performance of the organization. This result was achieved using a sample of 378 firms listed in China. These firms were firms that had gone through financial distress between 2000 and 2008.

Akhmetova and Batomunkueva (2014) examined the impact of board composition on financial distress in Sweden and Denmark. Study showed that internal governance system is a major factor that influences firm performance. The study used the Binary and multiple regression analyses to analyze the data for the financial prediction. Study further indicated that board independency had a significant relation with financial distress.

\section{RESEARCH METHODOLOGY}

\section{Research Design}

In determining the effect of corporate governance on financial distress of listed firms at Ghana Stock Exchange (GSE), the researcher employed both explanatory and descriptive research designs. Research designs were purposely employed to create awareness on financial distress situation. Questions of the form "what" were answered correctly by the help of descriptive and explanatory research designs. All questions that may rise in the process of the study can be answered by the research designs and hence processes involved for making research on the effect of corporate governance on financial distress of listed firms at Ghana Stock Exchange (GSE) (Gill \& Johnson, 2010) must be ushered by research designs. 


\section{Effect of Corporate Governance on Financial Distress: Evidence from Listed Firms at Ghana Stock Exchange}

\section{Population and Sample}

Based on rich history and consistency, 15 out of 42 firms were selected from firms at Ghana Stock Exchange at the later part of December 2019. In all the population comprised 42 listed companies on the Ghana stock exchange.

\section{Data Collection and Sources}

Yearly financial data of the selected 15 firms in Ghana Stock exchange were used to gather data for the study. GSE annual data that had been kept by the firm from 2015 to 2019 were gathered for the study and GSE handbook which have annually published data also provided data for the study. These comprised the total number of non-executive directors, board size (number of board members), board gender diversity (number of female board members) and ownership concentration (percentage number of shares owned by the management).

\section{Model Specification}

The model used for the study was ordinary least square (OLS) regression. The model was employed to show significant relationship among corporate governance practices and financial distress, which forms the study's variables. A multivariate regression analysis was also employed to establish a relationship between more than one variable in the study. The model is shown below:

$Y=\beta 0+\beta 1 X 1+\beta 2 X 2+\beta 3 X 3+\beta 4 X 4+\beta 5 X 5+\beta 6 X 6+\varepsilon$

Where $Y$-dependent variable (Financial distress)

$\mathrm{X} 1$ - Number of Non-executive directors

X2 - Board Size

X3 - Board Gender Diversity

X4-Ownership Concentration

$\varepsilon-$ Is the error term

$\beta$-Predictor variables coefficients

Table 1 Measurement of Variables

\begin{tabular}{|l|l|l|l|}
\hline Variables & Types & Data Source & Measurement \\
\hline Financial Distress & Dependent & Secondary Data & Altman's Z score \\
\hline $\begin{array}{l}\text { Number of nonexecutive } \\
\text { directors }\end{array}$ & Independent & Secondary Data & $\begin{array}{l}\text { Number of nonexecutive } \\
\text { directors }\end{array}$ \\
\hline Board Gender diversity & Independent & Secondary Data & $\begin{array}{l}\text { Number of Female } \\
\text { board members }\end{array}$ \\
\hline $\begin{array}{l}\text { Ownership } \\
\text { concentration }\end{array}$ & Independent & Secondary Data & $\begin{array}{l}\text { Percentage number of } \\
\text { shares owned by the } \\
\text { management }\end{array}$ \\
\hline Board size & Independent & Secondary Data & Total Number of Board \\
\hline
\end{tabular}

Source: Author's compilations

\section{Data Analysis Method}

Normality test, heteroscedasticity and multicollinearity analysis of the data must connect with the research objective \purpose (Kothari, 2004) when presenting the data. EVIEWS 10 was utilized in giving an appropriate analysis to the data. The findings of the study were presented in mean, standard deviation, minimum and maximum values that show the variables utilized in the study. The researcher used descriptive analysis to derive the major findings through tables and percentages for conducting the analyses. Validity and accuracy of models were ensured through the use of diagnostic strategies viz. normality, heteroscedasticity, autocorrelation and multicollinearity test. Degree of multicollinearity among variables is determined by employing correlation matrixes and variance inflation factors. Regression analysis helped present data in a suitable test statistics and tabular form. The study employed Altman Z score model as a research tool for calculating financial distress as indicated below. Bwisa (2010) us ed Altman's model applicability in predicting financial distress and discovered the model's applicability to be $80 \%$ therefore in using the model to calculate financial distress among listed firms at GSE, the study is justified. Moreover, Mamo (2011) also utilized the model to estimate financial distress in commercial banks and discovered the validity of the model was $80 \%$. 
Effect of Corporate Governance on Financial Distress: Evidence from Listed Firms at Ghana Stock Exchange

4. DATA ANALYSES AND DISCUSSION

Descriptive Statistics of Variables used in the Model

The variables in the model are described using means, standard deviations, skewness and kurtosis

Table 2: Descriptive Statistics

\begin{tabular}{lllllll}
\hline & $\begin{array}{l}\text { Financial } \\
\text { distress }\end{array}$ & Board size & $\begin{array}{l}\text { Capital } \\
\text { structure }\end{array}$ & Diversity & $\begin{array}{l}\text { Ownership } \\
\text { concentration }\end{array}$ & $\begin{array}{l}\text { Non- } \\
\text { executive }\end{array}$ \\
\hline Mean & 4.47 & 8.57 & 2.28 & 1.11 & 0.40 & 1.00 \\
Median & 4.94 & 7.00 & 0.44 & 1.00 & 0.55 & 0.00 \\
Maximum & 7.88 & 11.00 & 13.30 & 4.00 & 0.72 & 4.00 \\
Minimum & 0.87 & 5.00 & -0.25 & 0.00 & 0.02 & 0.00 \\
Std. Dev & 2.18 & 3.1 & 3.06 & 1.23 & 0.26 & 1.30 \\
Skewness & -0.42 & 0.42 & 1.76 & 0.49 & -0.48 & 0.77 \\
Kurtosis & 1.82 & 2.87 & 6.23 & 2.32 & 1.34 & 2.12 \\
Observation & 125 & 125 & 125 & 125 & 125 & 125 \\
\hline
\end{tabular}

Source: Author's compilations

As illustrated in the Table 2, the study revealed that financial distress recorded a mean score of 4.47 and a standard deviation of 2.18. Skewness under financial distress was recorded -0.42 and kurtosis 1.82 . Also, board size recorded 8.57 and 3.1 scores for mean and standard deviation each. A skewness of 0.42 and kurtosis of 2.82 were recorded for board size. Moving on with capital structure a mean score of 2.28 and standard deviation of 3.06 were recorded. Capital structure recorded skewness of 1.76 and kurtosis of 6.23

Again, the study found that, diversity recorded a mean score of 1.11 , standard deviation score of 1.23 , skewness of 0.49 and kurtosis of 2.32. Moreover, Ownership concentration recorded a mean of 0.40 , standard deviation of 0.26 and skewness of -0.48 . Kurtosis recorded 1.34 for management. Lastly, a mean score of 1.00 was recorded for non-executive. A standard deviation of 1.30 , skewness of 0.77 and kurtosis of 2.12 were recorded under non-executive.

\section{Diagnostic Tests of Normality, Heteroscedasticity and Multicollinearity}

The data have been validated using normality, multicollinearity and Heteroscedascity test as recommended by previous research due to their robustness. These have been detailed in the next section

\section{Test of Multicollinearity}

As showed in the table 3 using Breusch-Godfrey Serial Correlation LM Test the study found no multicollinearity problems in the model. All the null hypotheses for multicollinearity were rejected supporting the alternative hypothesis that the model does not contain multicollinearity

Table 3: Breusch-Godfrey Serial Correlation LM Test

\begin{tabular}{llll}
\hline F-statistic & 41.15488 & Prob. $F(2,117)$ & 0.300 \\
\hline Obs*R-squared & 51.62176 & Prob. Chi-Square(2) & 0.1560 \\
\hline
\end{tabular}

Source: Author's Estimation

\section{Test of Heteroscedasticity}

As presented in the table 4 using Breusch-Godfrey Heteroscedasticity LM Test the study found no Heteroscedasticity problems in the model. All the null hypotheses for Heteroscedasticity were rejected supporting the alternative hypothesis that the model does not contain Heteroscedasticity

Table 4: Heteroscedasticity

\begin{tabular}{llll}
\hline F-statistic & 2.541206 & Prob. F(5, 119) & 0.0319 \\
Obs*R-squared & 12.05908 & Prob. Chi-Square(5) & 0.0340 \\
Scaled explained SS & 5.772119 & Prob. Chi-Square(5) & 0.3290 \\
\hline
\end{tabular}

Source: Author's Estimation 


\section{Effect of Corporate Governance on Financial Distress: Evidence from Listed Firms at Ghana Stock Exchange}

\section{Test of Normality}

As indicated in the Figure 1 using Jarque Bera test statistics the study found the distribution of the data in the model as normally distributed. All the null hypotheses for Jarque Bera test statistics were rejected supporting the alternative hypothesis that the distribution of the model is normally. Moreover, skewness is 0 and kurtosis is less than 3.

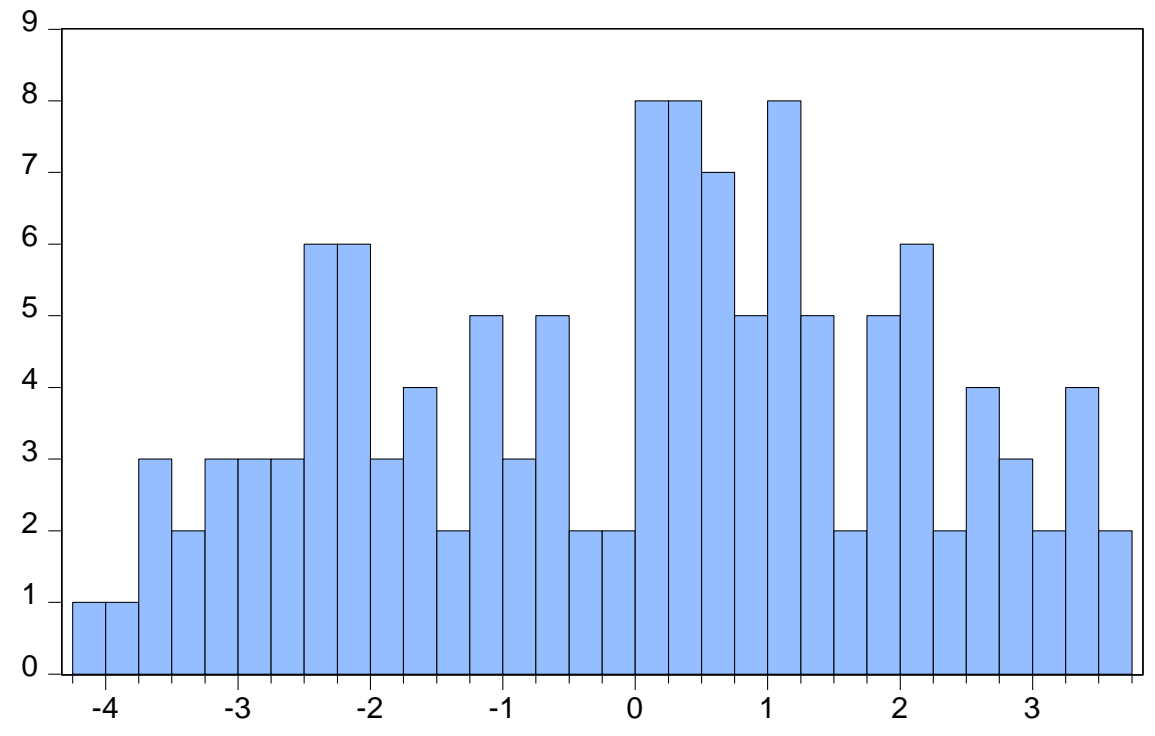

\begin{tabular}{|ll|}
\hline \multicolumn{2}{|l|}{ Series: Residuals } \\
Sample 2013 2137 \\
Observations & 125 \\
& \\
Mean & $3.62 \mathrm{e}-16$ \\
Median & 0.258336 \\
Maximum & 3.651608 \\
Minimum & -4.154197 \\
Std. Dev. & 2.007662 \\
Skewness & -0.152726 \\
Kurtosis & 2.056275 \\
& \\
Jarque-Bera & 5.124572 \\
Probability & 0.077128 \\
\hline
\end{tabular}

Table 5: Correlation Matrix

\begin{tabular}{|c|c|c|c|c|c|c|c|}
\hline & Profit & $\begin{array}{l}\text { Capital } \\
\text { structure }\end{array}$ & Management & $\begin{array}{l}\text { Non- } \\
\text { executive }\end{array}$ & $\begin{array}{l}\text { Board } \\
\text { size }\end{array}$ & Diversity & $\begin{array}{l}\text { Financial } \\
\text { distress }\end{array}$ \\
\hline Profit & 1 & & & & & & \\
\hline Capital structure & $\begin{array}{l}.321^{* *} \\
(0.000)\end{array}$ & 1 & & & & & \\
\hline Management & $\begin{array}{l}-.144 \\
(0.110)\end{array}$ & $\begin{array}{l}-.383^{* *} \\
(0.000)\end{array}$ & 1 & & & & \\
\hline Non-executive & $\begin{array}{l}.076 \\
(0.401)\end{array}$ & $.331^{* *}(0.000)$ & $\begin{array}{l}-.471^{* *} \\
(0.000)\end{array}$ & 1 & & & \\
\hline Board & $\begin{array}{l}.408^{* *} \\
(0.000)\end{array}$ & $.283^{* *}(0.001)$ & $\begin{array}{l}-.466^{* *} \\
(0.000)\end{array}$ & $\begin{array}{l}.221^{*} \\
(0.013)\end{array}$ & 1 & & \\
\hline Diversity & $\begin{array}{l}.433^{* *} \\
(0.000)\end{array}$ & $.306^{* *}(0.001)$ & $\begin{array}{l}-.311^{* *} \\
(0.000)\end{array}$ & $.171(0.057)$ & $\begin{array}{l}.413^{* *} \\
(0.000)\end{array}$ & 1 & \\
\hline Financial distress & $\begin{array}{l}.288^{* *} \\
(0.001)\end{array}$ & $-.107(0.234)$ & $.227^{*}(0.011)$ & $\begin{array}{l}-.238^{* *} \\
(0.007)\end{array}$ & $\begin{array}{l}.016 \\
(0.858)\end{array}$ & $\begin{array}{l}.074 \\
(0.409)\end{array}$ & 1 \\
\hline
\end{tabular}

**. Correlation is significant at the 0.01 level (2-tailed).

*. Correlation is significant at the 0.05 level (2-tailed).

Table 5 presents inter-construct correlation between the variables used in the model. The study found a significant $(r=0.288, p$ value $<0.05$ ) correlation between profit and financial distress. Meanwhile, capital structure had no significant correlation between financial distress $(r=-0.107, p$-value $>0.05)$. Moreover, the study reported a significant correlation between Ownership concentration and financial distress $(r=0.227, p$-value $<0.05)$. Again, the study reported a negative correlation $(r=-0.238, p$-value $<0.05)$ between non-executive and financial distress. However, board size ( $r=0.016, p$-value $>0.05)$ and diversity $(r=0.074, p$-value $>0.05$ ) had no significant correlation between financial distress.

Table 6: Effect of Corporate Governance on Financial Distress

\begin{tabular}{lllll}
\hline Variables & Coefficient & Std. Error & T-statistic & P-value \\
\hline Board size & 0.16 & 0.09 & 1.66 & 0.008 \\
Capital structure & -0.00 & 0.06 & -0.05 & 0.956 \\
Diversity & 0.34 & 0.18 & 1.86 & 0.054
\end{tabular}


Effect of Corporate Governance on Financial Distress: Evidence from Listed Firms at Ghana Stock Exchange

\begin{tabular}{|c|c|c|c|c|}
\hline Ownership concentration & -3.22 & 0.96 & -3.34 & 0.001 \\
\hline Non-executive & -0.18 & 0.16 & -1.12 & 0.264 \\
\hline Constant & 4.44 & 0.59 & 7.49 & 0.000 \\
\hline R-squared & & 0.155 & & \\
\hline Adjusted R-squared & & 0.125 & & \\
\hline S.E. of regression & & 2.04 & & \\
\hline Sum squared resid & & 499 & & \\
\hline Log likelihood & & -263 & & \\
\hline F-statistic & & 4.37 & & \\
\hline Prob(F-statistic) & & 0.001 & & \\
\hline
\end{tabular}

Source: Author's Estimation

As indicated in the Table $6 \mathrm{R}$-square result suggested that $15.5 \%$ variability in financial distress of listed companies is explained by corporate governance practices of the listed companies. This result suggests that a unit change in corporate governance practices will bring about $12.5 \%$ changes in financial distress management. The study found that board size was significant determinant ( $b e t a=0.16, p$-value $<0.05$ ) of financial distress. Again, the study further found that board diversity $($ beta $=0.34, p$ value $<0.05)$ was significant determinant of financial distress. Moreover, the study found that Ownership concentration $($ beta $=$ 3.22, $p$-value $<0.05$ ) of the board was significant determinant of financial distress. However, non-executive and the capital structure were not determinants of financial distress.

\section{DISCUSSION OF RESULTS}

The study found that board size was significant determinant (beta $=0.16, p$-value $<0.05$ ) of financial distress. Again, the study further found that board diversity (beta $=0.34, p$-value $<0.05$ ) was significant determinant of financial distress. Moreover, the study found that Ownership concentration (beta $=3.22, p$-value $<0.05$ ) of the board was significant determinant of financial distress. However, non-executive and the capital structure were not determinants of financial distress. Previous studies such as Shah (2016) found that, corporate governance practices had an insignificant relation with financial distress. The study was taken in the Pakistan's economy with the intent of fulfilling a contextual knowledge gap. Moreover, Manzaneque, Priego and Merino (2016) found that, corporate governance practices have a significant impact on firms that are financially distressed. Most at times, firms become financially burdened due to resource mismanagement and lack of effective corporate governance. But study established that, through corporate governance, firms can prevent financial distress to become effective in business operation. Besides, corporate governance would help enhance the capital structure of firms as well as increasing the net profit margin. Campbell, John, Hilscher and Jan (2011) discovered that, distressed shares tend to be lower in terms of performance and that these shares had greater market instability and face diverse risks. Besides, investors that are under distressed are unable to achieve rewards since the overall output of the organization is negatively impacted. Manzaneque, Priego and Merino (2016) who assessed corporate governance and monetary distress revealed that corporate governance practices have a significant impact on firms that are financially distressed. Most at times, firms become financially burdened due to resource mismanagement and lack of effective corporate governance. But study established that, through corporate governance firms can prevent financial distress to become effective in business operation. Besides, corporate governance would help enhance the capital structure of firms as well as increasing the net profit margin.

\section{CONCLUSIONS AND IMPLICATIONS}

This study was conducted to determine the effect of corporate governance on financial distress of listed firms at Ghana Stock Exchange (GSE) using panel data from 2013 to 2017. Specifically, the study focus on: The effect of board size on financial distress of listed firms at GSE, the effect of board gender diversity on financial distress of listed firms at GSE, the effect of ownership concentration on financial distress of listed firms at GSE and the effect of number of non-executives on financial distress of listed firms at GSE. The study broadly concludes that $15.5 \%$ variability in financial distress of listed companies is explained by corporate governance practices of the listed companies. This result suggests that a unit change in corporate governance practices will bring about $12.5 \%$ changes in financial distress management. The study found that board size was significant determinant of financial distress. Again, the study further found that board diversity was significant determinant of financial distress. Moreover, the study found that managerial experience of the board was significant determinant of financial distress. However, non-executive and capital structure was not determinants of financial distress. 


\section{Effect of Corporate Governance on Financial Distress: Evidence from Listed Firms at Ghana Stock Exchange}

The study found that that $15.5 \%$ variability in financial distress of listed companies is explained by corporate governance practices of the listed companies. Therefore, the following recommendations are made. First and foremost, the study suggests that selected firms at GSE must develop and formulate good policies to help regulate and manage board members so that the decision-making process of the firm can be facilitated to achieve firm goals and objectives while maintaining financial stability in their institutions. Also, the study recommends that selected firms at GSE must increase the number of non-executive board so that corporate governance practices can be enhanced to promote accountability and transparency in all internal activities thus reducing the financial distress position. Again an increase in management and control in an organization promotes the operational performance particularly in the financial performance of the firm. The study therefore recommends that management increase management practices to help decrease challenges affecting the growth and development of the firm. In this case, study suggests that selected firms should adopt effective strategies and measures to help ensure that activities are enhanced to promote effectiveness thus avoiding inter-conflicts between business owners and managers.

\section{REFERENCES}

1) Aasen, M. R. (2011). Applying Altman's Z-score to the financial Crisis. An empirical study of financial Distress on Oslo Stock Exchange. Master's Thesis, Norwegian School of Economics, Norway

2) Adams, R. and Mehran, H. (2008). Corporate Performance, Board Structure and their Determinants in the Banking Industry. Federal Reserve Bank of NY Staff Report No 330

3) Aguilera, R. V. \& Jackson, G. (2003). The cross-national diversity of corporate governance: Dimensions and determinants. Academy of Management Review, Vol. 28, No. 3, 447-465.

4) Akhmetova, A. and Batomunkueva, Y. (2014). Board composition and financial distress: An empirical evidence from Sweden and Denmark. Master's thesis, Umea School of Business and Economics.

5) Altman E.I. (1983). Corporate Financial Distress. New York: Wiley Interscience.

6) Altman, E.I. and Hotchkiss, E. (2006) Corporate Financial Distress and Bankruptcy: Predict and Avoid Bankruptcy, Analyze and Invest in Distressed Debt. 3rd Edition, John Wiley \& Sons, New York. https://doi.org/10.1002/9781118267806

7) Ashbaugh, H., Collins, D., and LaFond, R. (2004). Corporate governance and financial performance, International Journal of Business Administration, 3(1), 2.

8) Bredart, X. (2014). Financial Distress and Corporate Governance: The Impact of Board Configuration. International Business Research, 7(3), 72 - 80.

9) Bwisa H. (2010). "What is a cooperative?" SACCO Star, KUSCCO, issue 12, p11

10) Campbell, John Y., Jens Dietrich Hilscher and Jan Szilagyi (2011). Predicting financial distress and the performance of distressed stocks. Journal of Investment Management, 9(2): 14-34

11) Capital Market Authority (2015). Code of corporate governance practices for issuers of securities tothe public 2015 (Cap. 485A), for both listed and unlisted public companies in Kenya. Kenya Gazette Notice No. 1420

12) Crutzen, N. and Van Caillie, D., (2007a). The prevention of business failure: a state of the art,. Accounting History, October

13) Crutzen, N. and Van Caillie, D., (2007b). The business failure process: towards an integrative model of the literature. EIASM Workshop on Default Risk and Financial Distress, Rennes (France), September 13-14

14) Datta, N. (2018). Impact of corporate governance on financial performance: A study on DSE listed insurance companies in Bangladesh. Global Journal of Management and Business Research: D Accounting and Auditing, Vol. 18, Issue 2, 32-39

15) Dewji, H. and Miller, S. (2013). Assessing the components of effective corporate governance. Strategic Management Review, 7(1), 47-63.

16) Emery, D. R., Finnerty, J. D. and Stowe, J. D. (2007). Corporate financial management (3rd ed.). USA: Prentice Hall.

17) Gill, J and Johnson, P (2010). Research Methods For Managers (4th Edition Edn.). London: Sage Publications Ltd.

18) Hu, D., and Zheng, H. (2015). Does ownership structure affect the degree of corporate financial distress in China?. Journal of Accounting in Emerging Economies, 5(1), 35 - 50.

19) Hu, H. (2011). A Study of financial distress prediction of Chinese growth enterprises. Masters Thesis. University of Canberra.

20) Jensen, M. C. (1993). The modern industrial revolution, exit, and the failure of internal control systems. The Journal of Finance, 48(3), 831-880.

21) Jensen, M. C. and Meckling, W. H. (1976). Theory of the Firm: Managerial Behavior, Agency Costs and Ownership Structure (July 1). Michael C. Jensen, A theory of the firm: governance, residual claims and organizational forms, Harvard University Press, December 2000; Journal of Financial Economics (JFE), Vol. 3, No. 4, 


\section{Effect of Corporate Governance on Financial Distress: Evidence from Listed Firms at Ghana Stock Exchange}

22) Jiming, L. and Weiwei, D. (2011). An empirical study on the corporate financial distress prediction based on logistic model: Evidence from China's manufacturing industry. International Journal of Digital Content Technology and its Applications, 5(6), 368-379

23) Kalckreuth, U. von. (2005). A "wreckers theory" of financial distress (Discussion Paper Series 1: Economic Studies No. 2005, 40). Deutsche Bundesbank, Research Centre.

24) Kamau, G. (2018). Corporate governance and performance of financial institutions in Kenya. Academy of Strategic Management Journal, Vol. 17, Issue 1, 1-13

25) Kemboi Kipruto, E. (2013). The validity of Altman's failure prediction model in predicting corporate financial distress in Uchumi supermarket in Kenya.

26) Kirkpatrick, G. (2009). Corporate governance and the financial crisis. OECD, Financial Market Trends, 96(1), 1-30.

27) Knell, A. (2006). Corporate Governance: how to add value to your company: A practical implementation guide. Oxford: Elsevier.

28) Kothari, C. R. (2004). Research Methodology: Methods and Techniques. 2nd Edition, New Age International Publishers, New Delhi.

29) Labie, M. and Périlleux, A. (2008). Corporate governance in microfinance: credit unions, Working Papers CEB.

30) Lamichhane, P. (2018). Corporate Governance and Financial Performance in Nepal. NCC Journal, 3(1), $108-120$. https://doi.org/10.3126/nccj.v3i1.20253

31) Maina, F. G. \& Sakwa, M. M. (2012). Understanding financial distress among listed firms in Nairobi Stock Exchange: $A$ quantitative approach using the z-score multi- discriminant financial analysis model, PHD thesis, Jomo Kenyatta University of Agriculture and Technology

32) Mamo, A. Q. (2011). Applicability of Altman (1968) model in predicting financial distress of commercial banks in Kenya. University of Nairobi

33) Mandi, A. M (2014). An assessment of Kenya's sovereign risk of listed Firms (Masters Dissertation, University of Nairobi)

34) Manzaneque, M., Priego, A. M., and Merino, E. (2016). Corporate governance effect on financial distress likelihood: evidence from Spain. Revista de Contabilidad, 19(1), 111-121.

35) Md-Rus, R., Mohd, K. N. T., Latif, R. A. and Alassan, Z. N. (2013). Ownership Structure and Financial Distress. Journal of Advanced Management Science, 1(4), 363-367.

36) Outecheva, N. (2007). Corporate Financial Distress: An Empirical Analysis of Distress Risk. (Unpublished doctoral dissertation), University of St Gullen,Switzerland.

37) Rodriguez-Fernandez, M., Fernandez-Alonso, S., and Rodriguez-Rodriguez, J. (2014). Board characteristics and firm performance in Spain. Corporate Governance, 14(4), 485 - 503.

38) Sanda, A., Mikailu, A. and Garba, T. (2005). Corporate governance mechanisms and firm financial performance in Nigeria. Nairobi: African Economic Research Consortium

39) Senbet, L. W. and Wang, T. Y. (2012). Corporate Financial Distress and Bankruptcy: A Survey. Foundations and Trends in Finance, Forthcoming.

40) Shah, S. B. H. (2016). The impact of corporate governance on financial distress; Evidence from Pakistan (Doctoral dissertation, Capital University).

41) Shin-Ping, L., and Tsung-Hsien, C. (2009). The determinants of corporate performance: A viewpoint from insider ownership and institutional ownership. Managerial Auditing Journal, 24(3), $233-247$.

42) Taliani Julius (2012). Predicting financial distress in commercial banks in Kenya. Journal of finance, 5(5), 23-32

43) Wamugo, M. Makau, S. M. and Kosimbei, G. (2014). "Relationship between Capital Structure and Performance of NonFinancial Companies Listed In the Nairobi Securities Exchange, Kenya". Global Journal of Contemporary Research in Accounting, Auditing and Business Ethics, Vol: 1 Issue 2.

44) Zouari, S. B. S., and Taktak, N. B. (2014). Ownership structure and financial performance in Islamic banks: Does bank ownership matter? International Journal of Islamic and Middle Eastern Finance and Management, 7(2), 146 - 160.

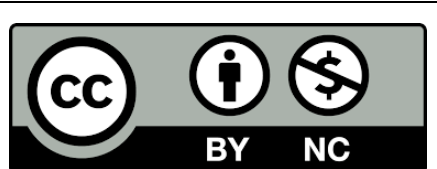

There is an Open Access article, distributed under the term of the Creative Commons Attribution - Non Commercial 4.0 International (CC BY-NC 4.0)

(https://creativecommons.org/licenses/by-nc/4.0/), which permits remixing, adapting and building upon the work for non-commercial use, provided the original work is properly cited. 